\title{
Sandhills, sandbanks, waterways, canals and sacred lakes at Sais in the Nile Delta
}

\author{
Penelope Wilson $^{1}$ and Hosni Ghazala ${ }^{2}$ \\ ${ }^{1}$ Department of Archaeology, Durham University, Durham DH1 3LE, United Kingdom \\ ${ }^{2}$ Geology Department, Mansoura University, Mansoura, Dakhalia Governorate, Egypt
}

Correspondence: Penelope Wilson (penelope.wilson@durham.ac.uk)

Relevant dates: $\quad$ Received: 30 July 2020 - Revised: 7 April 2021 - Accepted: 16 April 2021 Published: 25 May 2021

How to cite:

Wilson, P. and Ghazala, H.: Sandhills, sandbanks, waterways, canals and sacred lakes at Sais in the Nile Delta, E\&G Quaternary Sci. J., 70, 129-143, https://doi.org/10.5194/egqsj-70-129-2021, 2021.

Abstract:

The paper explores the relationship between the archaeological zones of the ancient city of Sais at Sa el-Hagar, Egypt, and the natural landscape of the western central Nile Delta and, in particular, the extent to which the dynamic form of the landscape was an element in the choice of settlement location. Furthermore, settlement at Sais has been determined to have existed at several locations in the immediate environs of the current archaeological zones from the Neolithic period, around 4000 BCE (Before Common Era), to the modern day, suggesting that the local environment was conducive to sustainable settlement, culminating in the establishment of a capital city in the 7th century BCE. The nature of the settlement, its immediate environs and waterway systems will, thus, be described, based on correlation of geological, geophysical, remote sensing and archaeological data, in order to establish if and when human interactions in the landscape can be determined to be reactive or proactive.

Kurzfassung:

Der Beitrag untersucht die Beziehung zwischen den archäologischen Arealen der antiken Stadt Sais (heute: Sa el-Hagar, Ägypten) und der natürlichen Landschaft des westlichen Zentrums des Nildeltas und insbesondere, welche Rolle die dynamische Landschaftsentwicklung bei der Wahl des Siedlungsstandortes spielte. Dies geschieht vor dem Hintergrund, dass von der neolithischen Periode um 4000 v. Chr. bis in die Neuzeit verschiedene Siedlungsareale an mehreren Stellen in der unmittelbaren Umgebung der heutigen archäologischen Bereiche von Sais existierten, was darauf hindeutet, dass die lokale Umwelt dieses Ortes günstige Bedingungen für eine nachhaltige Besiedlung bot, ein Umstand, der in der Etablierung von Sais als Hauptstadt Ägyptens im siebten Jahrhundert v. Chr. gipfelte. Basierend auf der Korrelation von geologischen, geophysikalischen, Fernerkundungs- und archäologischen Daten wird dementsprechend im Folgenden der Charakter der Siedlung, ihrer unmittelbaren Umgebung und des zugehörigen Flussnetzes im Hinblick darauf beschrieben, ob eine auch zeitlich genauer zu fassende Bestimmung menschlicher Interaktionen mit der Landschaft als reaktiv oder proaktiv möglich ist. (Abstract was translated by Eva Lange-Athinodorou.) 


\section{Introduction}

The archaeological site of Sais at Sa el-Hagar, Gharbiyah Governorate, Egypt (Fig. 1), has been studied since 1997, within its palaeo- and modern landscape, through a programme of archaeological survey and excavation combined with geoelectrical resistivity and magnetic survey as well as a manual drill coring programme (Wilson, 2006). The overall aim of the work was to understand the relationship and interactions between the archaeological settlement areas and the natural landscape features, in particular the waterways and buried sandbanks, from the period of the first human settlement at the site in Neolithic times, ca. 4000 BCE (Before Common Era), until the present day (Wilson et al., 2014). Furthermore, the dynamics of the landscape and human activity can be analysed for information about the extent to which the choice of area for settlement was dictated by naturally occurring favourable conditions, such as buried sand features and/or levees or levees, or by human political and economic choices connected with land and river management (Hritz, 2014, pp. 230-243). This paper will analyse the extent to which different types of data from geophysical, archaeological, remote sensing and ancient textual information can be combined to correlate and extend the interpretation of single data sets, in order to track waterways, buried sandhills, human settlement and other landscape interventions over the longue durée of 6000 years at Sa el-Hagar in a floodplain dominated by an ancient river system.

\section{Methods}

The study area is the floodplain the west of the Rashid (Rosetta) branch of the Nile where there are a number of towns and villages within a drain and canal network, mostly consolidated in the 19-20th century by the engineers of Muhammad Ali and the Ministry of Public Works (Barois, 1904, pp. 119-124). First, to reconstruct the palaeolandscape of the area, the University of Mansoura team made 19 deep-drill cores, up to $23 \mathrm{~m}$ deep, and six transects of 41 vertical electrical soundings (VESs; using a Schlumberger array) to trace the development of the landscape from the Pleistocene to the Holocene eras (Fig. 2; Ghazala, 2005; ElShahat et al., 2005).

In addition, information from historical satellite imagery, such as CORONA and Google Earth, and from individual Landsat 5 images was also compared with the geophysical survey data to detect subsurface relict waterways (Abrams and Comer, 2013; see Pope and Dahlin, 1989; for Egypt, see Wunderlich, 1989). Then, from 1999 onwards, the geoarchaeological programme of the Durham-Ministry of Antiquities mission made over 300 shallow cores with a manual Eijkelkamp drill auger in the area (Wilson, 2006). The analysis of the core material showed that the human material culture layers usually do not extend beyond 6 to $7 \mathrm{~m}$ below the ground surface, except in some higher ground in the Kom Rebwa archaeological area. Deposits recorded in augers in the surface and buried archaeological zones included reworked primary settlement material, buried primary archaeological strata and, in some places, up to $8 \mathrm{~m}$ of continuous anthropogenic strata and layers of archaeological material apparently separated by alluvial sediments. Elsewhere, the augers contained purely geological sediments consisting of silts, hard compact clay and sandy-silt mixtures, as well as medium and fine sands (Wilson, 2006). Further data were collected from archaeological excavations (Ex's) in the Great Pit area (Ex 8) and in Kom Rebwa (Ex's 1-12), where fine-grained archaeological strata can be compared with drill auger data from the same place (Wilson, 2011; Wilson et al., 2014) to correlate the two sets of material more closely, to provide an understanding of anthropogenic material within drill cores and to integrate the geological and archaeological material. Finally, an ancient textual source was compared with the excavated and survey data to determine the limits of the source in answering specific questions without further topographical information. The correlation of the data can be used to refine chronological developments of human activity as it was played out in the dynamic floodplain environment.

\section{The geological framework}

Analysis of the underlying geology of the delta has identified the following four main phases and strata (Pennington, 2017; Pennington et al., 2017): at the base, the Mit Ghamr formation comprises Pleistocene medium coarse sands with an uneven surface, created by downcutting river systems (in some areas, the Mit Ghamr surface is covered by a layer of aeolian and reworked fluvial sand); next, and key to the period of human activity in the delta, is the deposition of the Bilqas 2 mud around 8000-7000 BP (Before Present) upon the surface of the Pleistocene fluvial sand, creating an undulating topography in the delta, with some sandhills, dynamic anastomosing channel networks, swampy floodplain and peat formation in some areas. Starting in the central and southern delta, there was a transition from the large-scale crevassing action of the river to the meandering river channels (Pennington et al., 2016) and from the Bilqas 2 muds to the Bilqas 1 layer around $6000-5500 \mathrm{BP}$, so that, by ca. $4500 \mathrm{BP}$, all of the delta was covered in Bilqas 1 sediments. This layer of brown silt clay ranged from 2 to $9.9 \mathrm{~m}$ thick and contains limestone nodules and gypsum rosettes according to periods of warm, arid conditions. The upper alluvial mud is essentially the layer in which human activity is detected.

In the Sa el-Hagar area, the detailed geological reconstruction of the area (Fig. 3) is based on the VES and deepdrill cores (Ghazala, 2005; Ghazala et al., 2005) and modelled scenarios of the main geologic strata from deep cores and the shallow-core drilling programme (Pennington, 2017, pp. 176-183). The analyses suggests that buried sandhills are located under the village of Kawady northeast of Sais, run- 


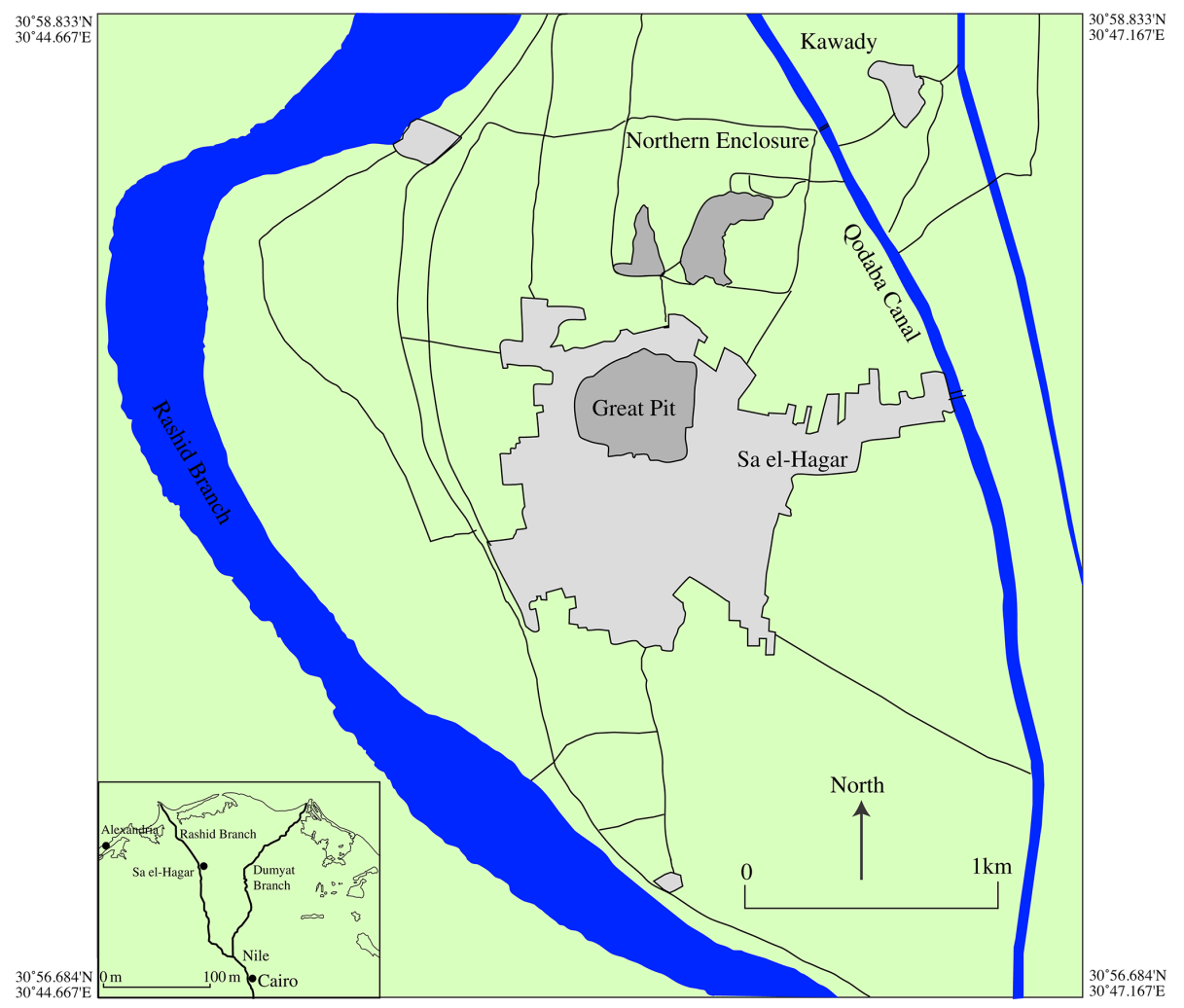

Figure 1. Map showing the location of the area of Sais, the archaeological zones and the modern town of Sa el-Hagar in the Nile Delta.

ning southward, and another sandbank runs along the eastern river bank on the western side of the area. In the region, other buried, elevated sands lie to the west of Basioun and in a large body running north to south to the east of the Sais area. The latter may have been a significant sand body separating the western river channels (the Canopic and Saitic branches) from the Sebennytic branch running through the centre of the delta.

The uneven Mit Ghamr surface also suggests that there were deep swampy basins north of Sais and, potentially, the course of a deep, older river channel to the east of Basioun flowing northward to Shubra Tana but with a distributary branching west, under what is now called the Great Pit, then turning in a meander back to the northeast and under what is now called the Northern Enclosure. A younger channel, mirroring the channel of the distributary but just a little south of it, has also been detected on the western side of the village of Sa el-Hagar and west of the Northern Enclosure. It seems likely that, over time, the river has continued this westward meander to its present location, leaving behind reworked sandbars on the inside of the bend of the modern Rashid or Rosetta branch at Sa el-Hagar. The environment in the period 4000-3500 BCE could be characterised as one of swamps and anastomosing river course, with higher land in isolated locations (Pennington, 2017, pp. 180-183), there- fore making it ideal for settlement and river exploitation during the Neolithic period.

\section{Data correlations}

This section discusses the correlation of different types of data and their analysis.

\subsection{Correlating geological survey and drill augers to the south of Sa el-Hagar}

Shallow drill augers to the southeast of the village of Sa el-Hagar (Fig. 4), contained thick bands of bivalve mollusc shells, confirming the reconstruction of a series of channels or waterbodies here at one time, i.e. the cores labelled C107, C103, C102, C101 and C182 and C183 (Fig. 5). The thick shell bands were also associated with silts and sands that were blueish or turquoise in colour and were, thus, at the interface between the Bilqas 1 and Mit Ghamr formation. C119 and C120 to the east, and between the two transects above, are shown for comparison without the thick bands of shell material and only have a few fragments representing the floodplain of the channels. It can also be noted that C107 and C102 had pottery fragments underneath the shell layers, suggesting that prehistoric human activity had been interrupted by a new channel in the same location (see below). 


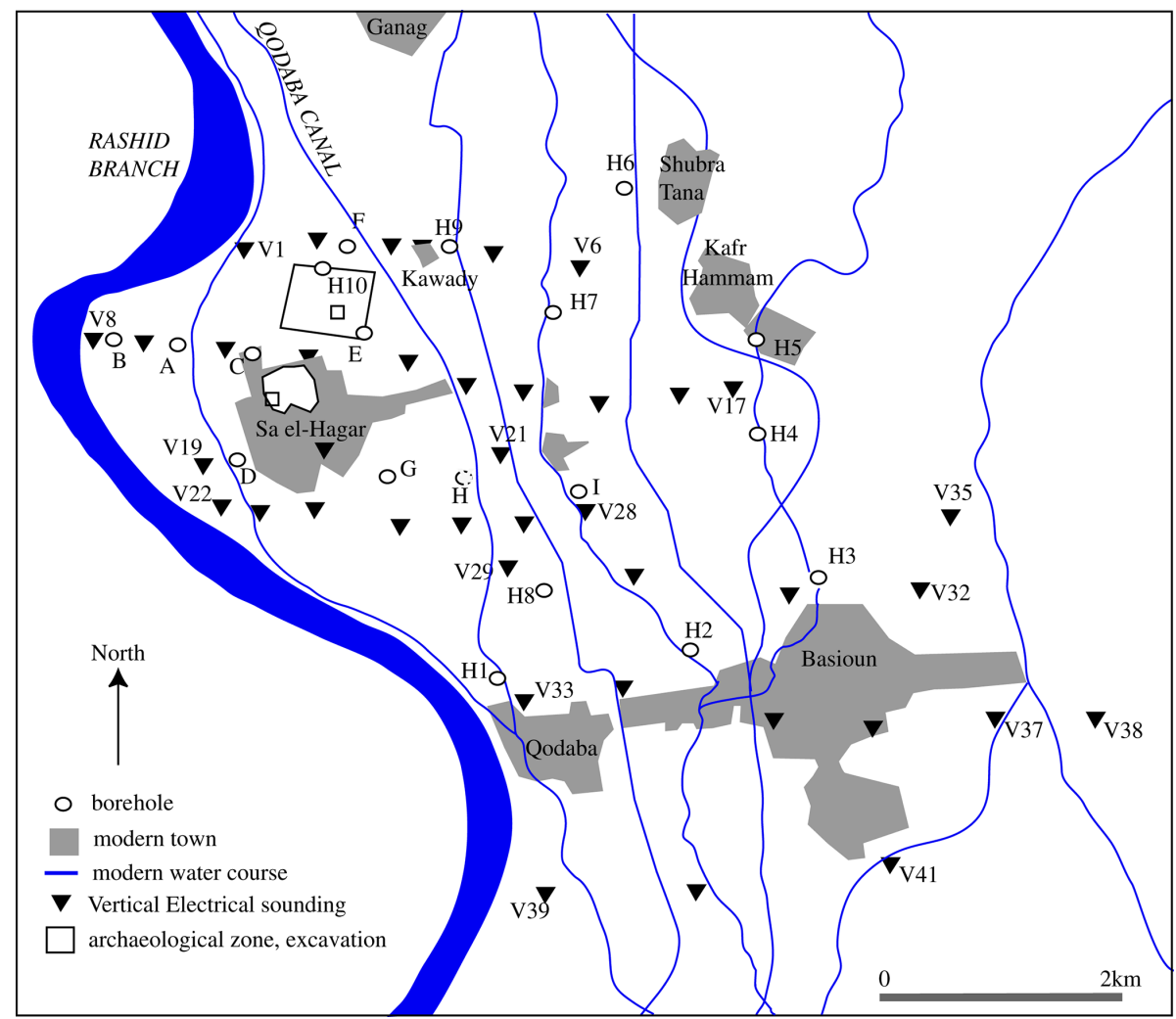

Figure 2. Area of Sa el-Hagar with the location of VES transects and deep-drill augers (after Ghazala, 2005).

\subsection{Correlating the geophysical model, remote sensing data and drill auger data}

The proposed younger channel has left a strong signal in satellite imagery and drill augers on the western side of the Northern Enclosure archaeological area. A Landsat 5 TM (thematic mapper) image of wavelength 5 (shortwave infrared; USGS, 2020) shows a dark band along the western side of the enclosure, almost parallel to it, due to relative water retention of sediments, and is most likely to be related to grain-size effects of buried river branches (see Ullmann et al., 2020; this Special Issue; Fig. 6). The band is an average of $200 \mathrm{~m}$ in width, similar to the narrow part of the modern Rashid branch bend at Sa el-Hagar.

A transect of the drill augers (C5, C191, C189, C63; Fig. 5) in the location of the band (Fig. 7) shows an upper $2.8 \mathrm{~m}$ of sediments with anthropogenic material in it, including broken limestone, orthoquartzites and pottery; then there are bands of finer silts and sands with broken bivalve mollusc shells (Cyrenidae family) in a $30 \mathrm{~cm}$ thick band, from 4 to $4.30 \mathrm{~m}$ below the ground surface in C189 and 3.5-4 m below the surface in C191. In the latter cores, the shell and sediment deposits continue for as much as $6.68 \mathrm{~m}$ belowground. But in C189, the core has a band of further anthropogenic material; apparently the channel cut into a previous area of human activity or deposition of material. In C189, there was especially dense anthropogenic material, and in fact, the core was stopped when the drill head hit a stone and could not proceed further at $7.25 \mathrm{~m}$ below the ground.

The pottery and other burnt material recovered from the lower part of the cores was potentially Predynastic in date, and this depth of material might well link with the prehistoric layers to the south in Ex 8 (see below). The satellite image, thus, seems to show the buried presence of a filled-in channel, with the sediments on top of the shell layer retaining more water than the sediments on either side. Such a strong signal cannot be detected in the satellite imagery elsewhere in the Sa el-Hagar area, and it may be that elsewhere the surface layers are too disturbed or built over by modern structures, as in the area to the south of Sa el-Hagar.

\subsection{Correlating geological soundings and archaeological excavation}

The river channel shift from the Great Pit area to the west can perhaps be detected in archaeological excavations in the Great Pit. A date can also be suggested for the movement of the channel. In Ex 8, the earliest level found was a fish midden of the Neolithic period, ca. 4300-4000 BCE, after radiocarbon dating and comparison of the pottery and lithics with other Neolithic sites in Egypt (Wilson el al., 2014). By correlating the archaeological section and drill augers (Fig. 8), it 


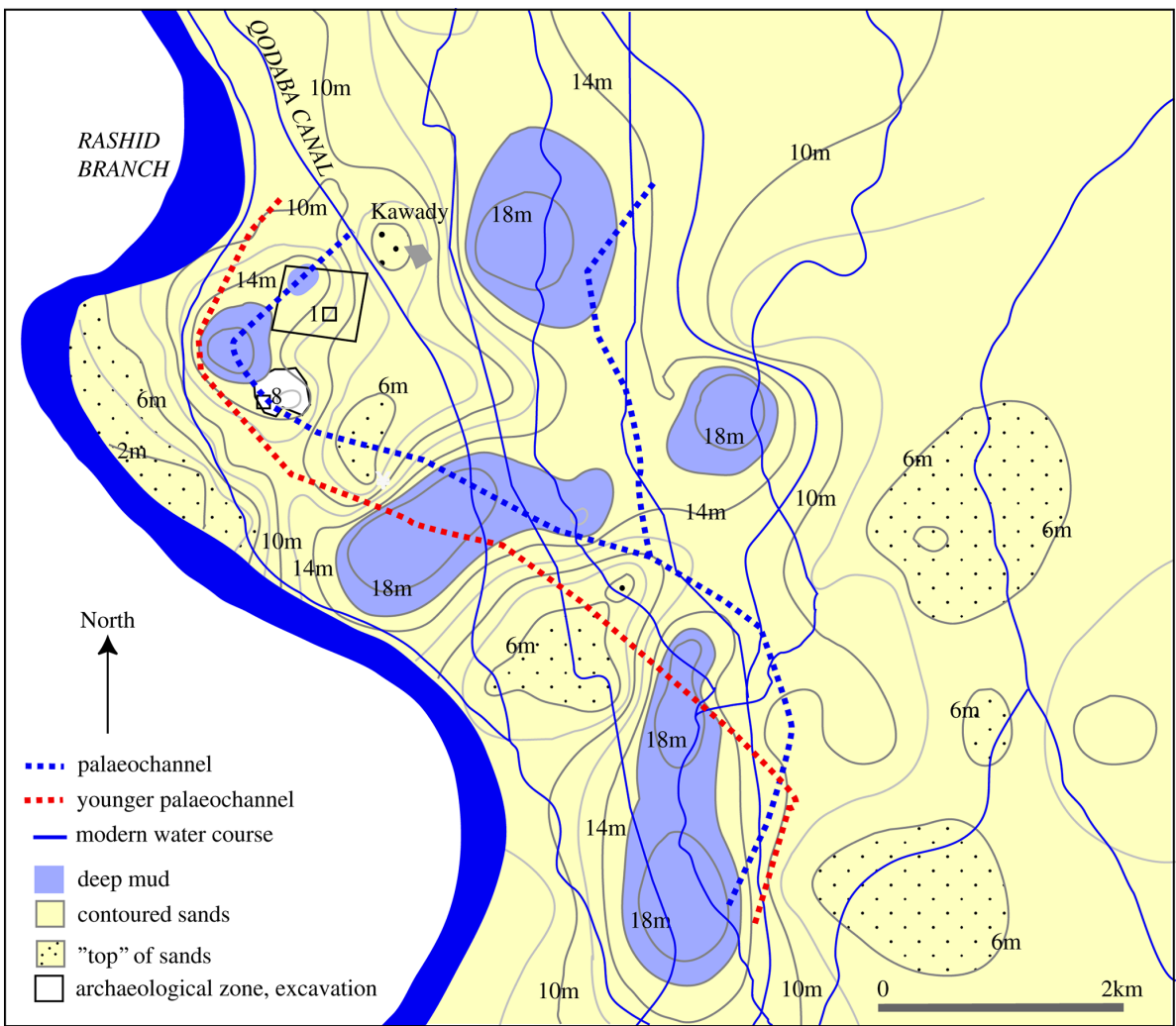

Figure 3. Map of the Sa el-Hagar area, with reconstructed subsurface sand contours up to $18 \mathrm{~m}$ below the ground, and the palaeochannel locations.

seems that the fish midden was situated on the western side of a riverbank (Mit Ghamr formation), which was then subject to flooding (Bilqas 1), and a settlement was established in the same location, which had evidence for semi-domesticated cattle, pigs and sheep goats. The area may have been subject to an arid period before the inundation increased to such an extent that the settlement area was abandoned and left to alluvial deposition (Bilqas 2) for some time until a reoccupation in the Buto-Maadi period, ca. 3500 BCE. The change in the alluvial regime could represent the shift of the river from the older channel to the younger channel, at which point human activity, if not settlement, resumed on the alluvium in the same place, at around 3500 BCE, until the Early Dynastic period around $3000 \mathrm{BCE}$, but was then situated on the eastern bank of a river channel.

The date of the change between 4000 and 3500 BCE seems to agree well with recent radiocarbon dates and pollen data from Sa el-Hagar (Zhao et al., 2020) that show the beginning of cultivated (domesticated) Poaceae cereal in the area during a period of warmer climate and expansion of the wetlands between 4750-3850 BCE (zone III), followed by a drier period with shrinkage of the wetland 3850-3550 BCE (zone IV) and then the recovery of the wetland from 35502250 BCE before the onset of a global, drier arid event 22502050 BCE. The key period of zones III to IV, when the older deep channel was abandoned through reduced water burden or a crevasse splay, was detected from coring at depths of 6.32 to $5.48 \mathrm{~m}$ below the ground (e.g. C41 in the north (Fig. 4) and C107 and C102 in the southeast; Fig. 5), consistent with reaching the Neolithic levels in Ex 8. In C107, there were blue-green coloured silts at the end of the core, and from this location, the bank of a possible water body would be on the same trajectory as the bank in Ex 8. Furthermore, $\mathrm{C} 107$ has a thick layer of settlement and anthropogenic material under the shell layer, but it is on top of coarse sands, at about $6.4 \mathrm{~m}$ below the ground surface, which may be redolent of the Pleistocene sand surface. The change in the river channel may have meant the replacement of human activities focussed on the exploitation of the river and water bodies in the Neolithic period, with humans settling on alluvial land with high areas and swampy backwaters that were attractive for settlement and exploitation of the agricultural, wetland and riverine resources in the Late Predynastic and Early Dynastic periods (ca. 3500-3000 BCE; Wilson, 2014).

The stratigraphic record, however, cannot be followed further in the Ex 8 area because, directly upon the Buto-Maadi period layers, is material from the destroyed structures dating to the Saite period at the end of the 6th century BCE. It seems likely that, in the Saite period, the area was cleared down to the sandy sediments for the purpose of founding new 


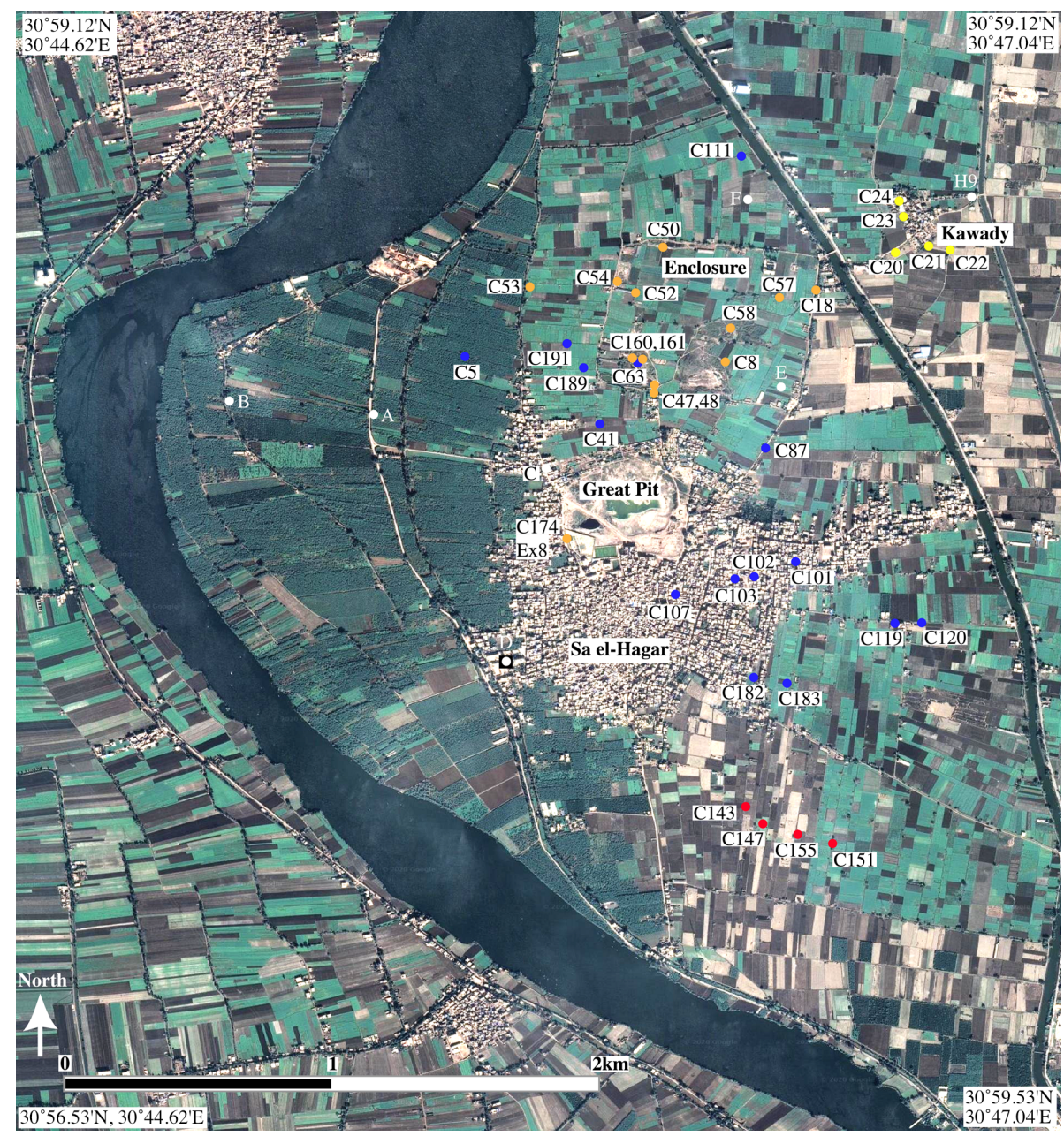

Figure 4. Map of drill core transects discussed in the article in the area of Sa el-Hagar. This figure has been generated from QGIS (Quantum GIS) and satellite images. (C) Google Earth.

monumental structures in the area. Whatever happened there in the intervening 2800 years was removed by human action, demonstrating that, although riverine activity can have shortterm and long-term impacts, human intervention on geological layers can also be substantial.

\section{Analysing the archaeological data from drill cores}

According to the scenarios above, the current configuration of the river to the west, and perhaps other channels to east, of Sa el-Hagar suggests that there has been little change since the beginning of the Dynastic period and that anthropogenic material occurs in the $6 \mathrm{~m}$ or so of alluvium after the Bilqas 1-Bilqas 2 transition. The identification of settlement layers and alluvial layers from drill cores alone, without contextual data, can be difficult. At Sa el-Hagar there are areas of positive archaeological settlement data, which can help in the analysis of core material where there are no other contextual data.

\subsection{Northern Enclosure - monumentalised settlement}

The Northern Enclosure area, although much flattened and denuded now, once contained massive mud brick and stone structures, including an enclosure wall some $700 \mathrm{~m}$ by $680 \mathrm{~m}$ in dimension, which is now reduced to a track (Wilson, 2006, pp. 99-115). The archaeological material in the enclosure has been extensively removed so that it is not even certain that this was the location of the famous temple of Neith. The drill augers have proved useful in the enclosure, not only identifying the depth of settlement and archaeological material but also, in some places, the nature of that material (Figs. 4, orange dots, and 9).

A transect across the Northern Enclosure (Fig. 9) shows the landscape in which the settlement is situated and the deep bands of human material culture (Wilson, 2006, pp. 180202). C53 is the channel, and its in-fill is to the west of the Northern Enclosure described above. The area seems to be virgin land and has no anthropogenic material in it, i.e. archaeological material defined as pottery, stone, burnt mate- 

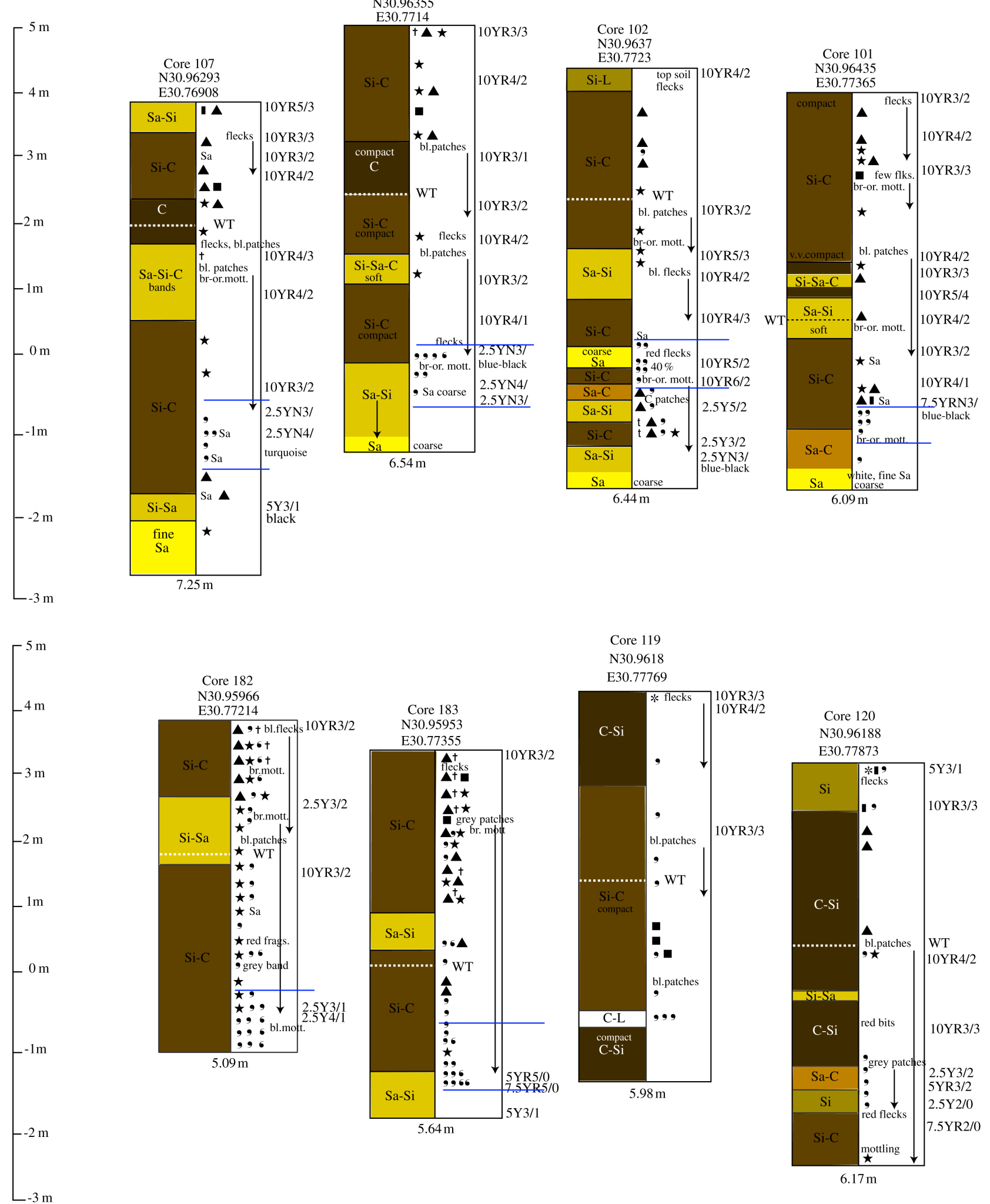

Figure 5. Transects southeast of Sa el-Hagar showing the following thick shell bands (blue lines): C107, C103, C102, C101 and C182 and C183, with C119 and C120 for comparison (see Fig. 13 for the key to cores). 


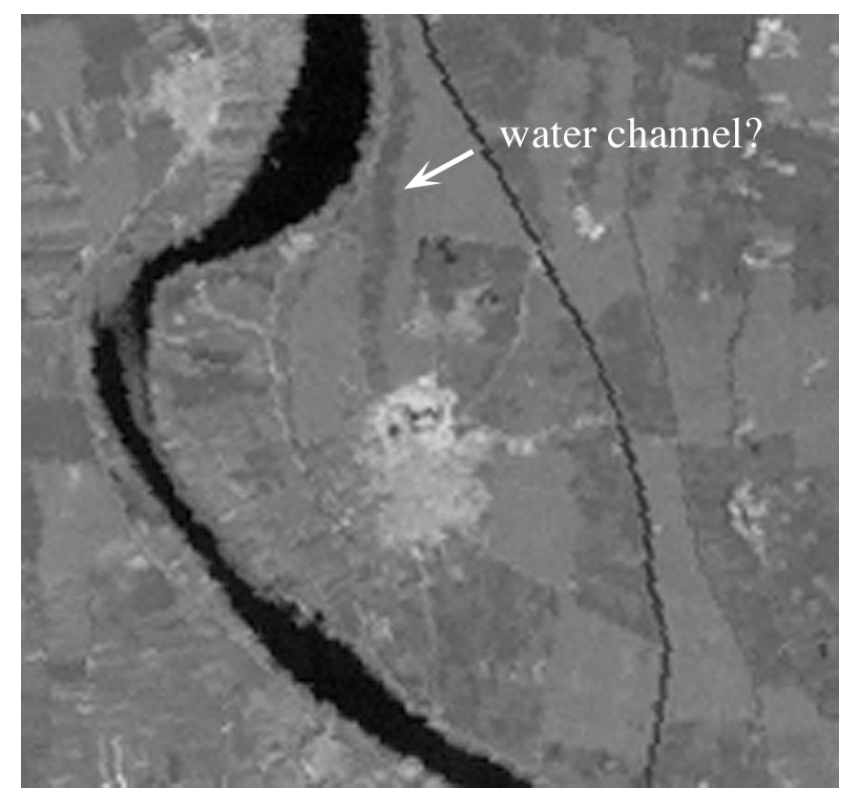

Figure 6. Extract from Landsat 5 data, showing the subsurface water features west of the Northern Enclosure at Sa el-Hagar (water absorbs infrared energy and gives no return; thus, this detail appears to be greyish black). Base map source: USGS Landsat 5; 14 February 1998 (original image courtesy of the U.S. Geological Survey).

rial and bone concentrations. By contrast, C54, just inside the enclosure, shows dense stone fragment layers, which are the remains of destroyed stone structures in the top $5 \mathrm{~m}$ of the core. The stone fragments are of limestone, granite and orthoquartzite, especially in a band $4-5 \mathrm{~m}$ below the ground, and these were the standard materials used for monumental structures. The stone layer is directly situated upon compact clay, which could be a natural levee acting as a foundation or a mud brick construction, in turn, upon other settlement material. The sequence may suggest that there was a building or gateway in the western side of the enclosure built upon pre-existing settlement layers. Earlier human activity was evidenced within alluvial layers, to a depth of at least $8 \mathrm{~m}$ below the modern ground level in C54. C52, to the east of C54 inside the Northern Enclosure, has silt clay and clay upper material, and there is a stone debris layer between 4 and $5 \mathrm{~m}$ from ground level, perhaps the foundations of a stone structure, apparently upon clay mud, with a thin band of pottery at $6.25 \mathrm{~m}$ signalling an initial settlement layer upon compact clay river levee material. C50 in the northern wall of the enclosure also has thick layers of stone debris (limestone, granite and orthoquartzite) with pottery for a depth of almost $7 \mathrm{~m}$, including a black gloss sherd, with brown and orange-red bands $(3.5 \times 2.7 \times 0.4 \mathrm{~cm}$; $\mathrm{C} 50$ and $\mathrm{C} 43)$ that may be east Greek in origin, and this, thus, points to a date in the 7th-6th century BCE. The latter would directly suggest a Saite period date for some aspect of the stone structure, and its depth at $5.22 \mathrm{~m}$ below ground level shows the difficulties of dating archaeological layers in terms of the depth alone. There are also thick layers of stone material, for example in C57 between 4.5 and $6 \mathrm{~m}$ below the ground. But above the stone debris is a band of anthropogenic material, from 3.14 to $4.5 \mathrm{~m}$, suggesting that the stone debris is from an earlier phase of monumental building in the eastern part of the enclosure. It may be that the stone structures were reorganised in a new phase of the site's history. In the eastern enclosure wall it is possible that the upper metre is the last part of the mud brick wall, which seems to have been founded on earlier settlement material, including an alluvial or mud band between and 2 and $3 \mathrm{~m}$ below ground. Other stone debris was recorded at the entrance to the Northern Enclosure in C47 and C48 (not illustrated), where the drill head could not penetrate the debris easily; this may suggest a gateway entrance to the enclosure or part of a monumental area.

As the enclosure is an identifiable archaeological zone with two low mound areas known that are protected Antiquities land, it is not unexpected to find considerable evidence of human activity, as detailed above. But the material from the cores can be directly compared with material from archaeological excavations, especially in Ex 1. Starting from datable layers and working downward through known archaeological features, the information from the drill cores can be contextualised, to some extent. C58 was drilled through a mud brick wall dating to the late Ramesside period (ca. 1189-1077 BCE) and was compared with subsequent excavation in this area (Wilson, 2011, p. 25; Fig. 25). The wall was known to have a height of over $1 \mathrm{~m}$ but was not completely excavated; in the core, the upper $1.64 \mathrm{~m}$ was a homogeneous mixture of silt clay with some pottery fragments, which is expected as walls were constructed by reusing settlement muds with pottery added for strength. The base of the wall seemed to be indicated by a layer of sand, possibly within a foundation trench or on top of earlier settlement debris to a depth of $2.76 \mathrm{~m}$ and aligned in the excavation section with the base of a series of ovens constructed in the area enclosed by the wall. The excavation ended after about $3 \mathrm{~m}$ of depth from the ground level due to reaching the water table and a layer of mud with blueish-black clay lumps in it, which was perhaps an alluvial layer. Pottery dating to the Old Kingdom had been found in this lower level. The drill core was able to proceed further, reaching the base of the alluvial layer at $3.64 \mathrm{~m}$ from its start, and another strong settlement layer was encountered, possibly topped by a burial ground due to the bones found between 3.64 and $4.9 \mathrm{~m}$. The drill auger then continued through alluvial layers, including an apparent in-filled channel at $6.7-8 \mathrm{~m}$, and through a compact clay levee down to $9.5 \mathrm{~m}$. In archaeological terms, the presence of Old Kingdom layers within alluvial mud underlying the New Kingdom material is interesting. Little Middle Kingdom material has been found at Sais, and the period is regarded as having had high inundations (Vercoutter, 1966; Bell, 1975), which may have affected settlements adversely. The alluvial band between the two dateable settlement layers may thus 


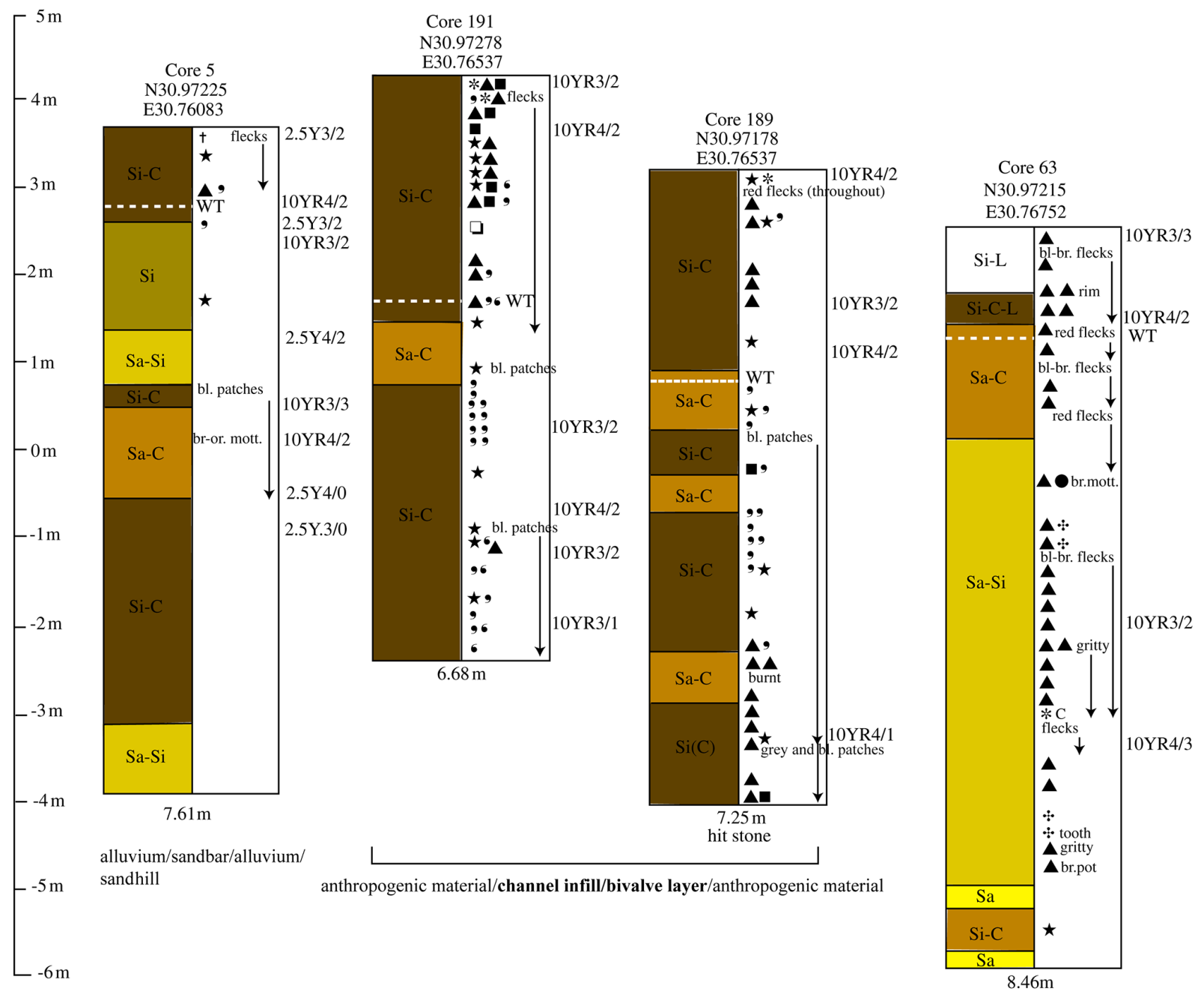

sandhill/sandbank/anthropogenic material

Figure 7. Transect (cores 5, 191, 189, 63) to the west of the Northern Enclosure, showing the channel and difference between alluvial and archaeological zones. Ground heights are taken from TanDEM-X data. (See Fig. 13 for the key to cores.)

be significant, implying that the old settlement area had been flooded. In the eastern side of the enclosure, $\mathrm{C} 160$ was made through Ex 5, and C161 was made through Ex 6. In Ex 5, upper levels dating to the Third Intermediate Period (TIP), ca. $1000-800$ BCE, were found to be upon a cemetery, perhaps of the New Kingdom, and contained disturbed material from the late Second Intermediate Period, ca. 1500 BCE; Ex 6 had a similar stratigraphy but was closely dated by TIP structures lying over early New Kingdom burials (ca. 1400 BCE). In the drill cores, there were several phases of settlement material from the ground surface, with changes in the matrices perhaps indicating phases of activity. The drill core information is useful in pinpointing the depths of archaeological material that are otherwise not possible to access. With better typologies of the pottery, it may be possible to have more confidence in dating the small, but numerous, fragments that have been collected from the drill cores, as has been done at Buto
(Hartung et al., 2009, pp. 172-188) and at Thebes (Toonen et al., 2017). In C161, there was almost constant settlement debris to a depth of $8.88 \mathrm{~m}$ below the ground, suggesting longlived and continuous human activity over a long period, especially allowing for the fact that the upper level begins at about $800 \mathrm{BCE}$, because any later settlement material has been removed. The deepest hand-drilled core in the enclosure area is C8, to a depth of $10.51 \mathrm{~m}$ at the edge of the eastern side of the Antiquities land (not illustrated). This core has deep strata of possible reworked anthropogenic material - which means that the layers are not so well defined, but there is good deal of pottery and other material - to $4.75 \mathrm{~m}$ and then alluvial layers or solid mud material in bands upon a thin layer of degraded pottery fragments at 7.8 to $8 \mathrm{~m}$ and compact alluvial levee clay to $10.5 \mathrm{~m}$. It seems, therefore, that below the $8 \mathrm{~m}$ limit there is no anthropogenic material at the site, and we may regard this as the Neolithic boundary. Similarly, Man- 


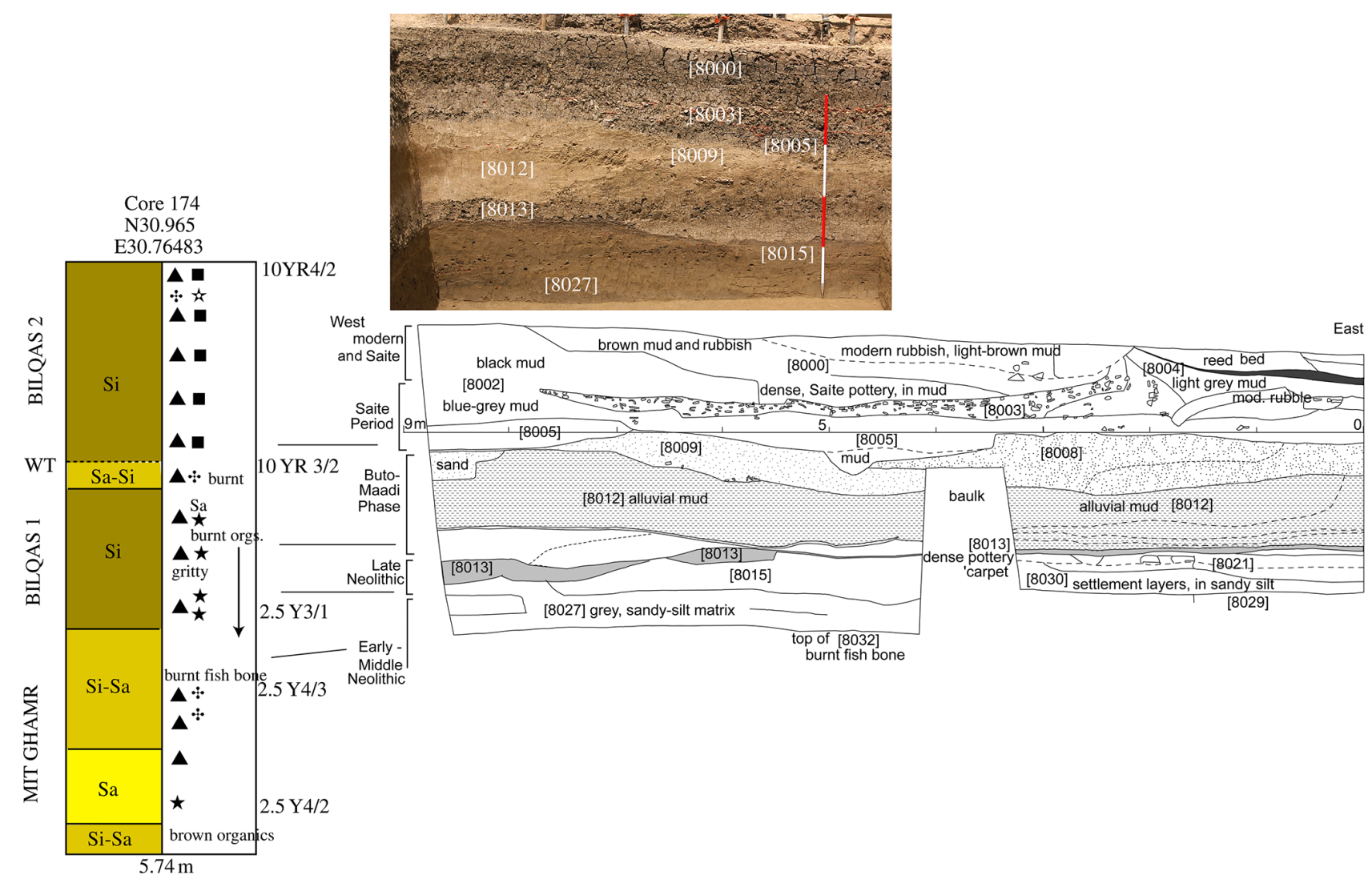

Figure 8. Correlation of archaeological strata in excavation 8 with drill core 174. Original data were taken from Angus Graham. (See Fig. 13 for the key to cores.)

soura cores E, to a depth of $11 \mathrm{~m}$, and $\mathrm{H} 10$ (for location, see Fig. 2), to a depth of $16 \mathrm{~m}$, detected anthropogenic material only in the upper $6 \mathrm{~m}$ of the cores.

\subsection{Kawady sandhill and archaeology}

A second archaeological zone is at Kawady (Ezbet Mohamed Ismail) to the northeast of the Saite area, where there is a buried sandhill (Figs. 2 and 3). According to theories of settlement patterns in Ancient Egypt, such a high-sand area should have provided an attractive place for settlement on the sides of the sandbank, with cemeteries being placed on the top to avoid the annual flooding. Excavations by the Egyptian Antiquities Service in 1961-1962 and 1965 discovered an elite cemetery area to the west of Kawady village, most likely consisting of a mausoleum structure that had contained limestone and basalt sarcophagi and a shrine to a local saint called Wahibre in the Saite period (Bakry, 1968). Drill cores in this area have located the sand lying relatively close to the surface, overlain by sandy silts that are often blue-black in colour (Fig. 11).

On top of these sands are strong anthropogenic signals from the ground level as far as the sand, suggesting that, indeed, this sandhill was an attractive area for human activ- ity. In C20, C21 and C23, the stone debris in bands down to $1.5 \mathrm{~m}$ below the ground may correlate with the Saite elite cemetery area. Further work is needed on the identification of the pottery fragments to show whether this area was used from much earlier periods. The drill cores and vertical electrical soundings from villages further to the east at Shubra Tana, Kafr and Bahr el-Hamam also suggest that there is archaeological material at depth here. Although coring in all places has indicated human material culture in the upper layers, including observed Roman amphorae, deeper deposits have only been identified in Kafr el-Hamam C2 (G6) between 2 and $4 \mathrm{~m}$, which may well be ancient, but it is unclear how ancient. The pattern of waterways, the positioning of settlements and the Roman-Late Roman material from some of the villages may suggest that this area was part of the irrigation system established during the Roman period in the area. As the system is visible in the current landscape, it cannot be very ancient, i.e. Late Roman or medieval at most, and is more likely from the 19th century during the irrigation projects from the Muhammad Ali era onwards. 

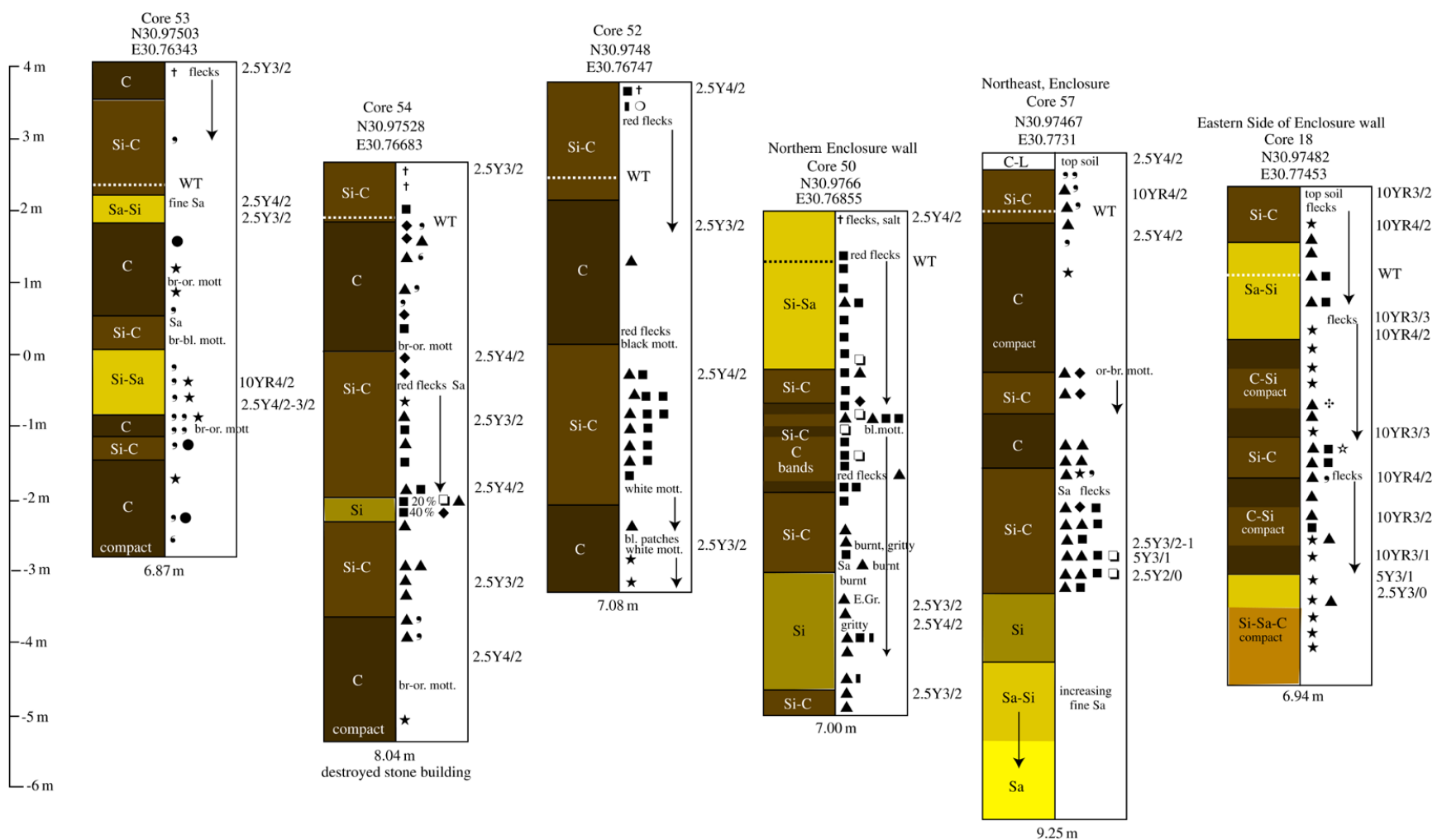

Figure 9. Transect of drill cores across the Northern Enclosure at Sa el-Hagar (C53, C54, C52, C50, C57 and C18) (see Fig. 13 for the key to cores).

\subsection{A new southern settlement?}

The geological reconstruction of the area to the southeast (Fig. 3) shows buried high ground that may also have been a focus for human activity that is no longer visible as an archaeological zone but can be detected in drill augers. Analysis of the core data has determined the following four types of core data at Sais: (1) human (anthropogenic) material culture (HMC) for the whole length of the drill core, with a high level of confidence that pottery, for example, had not dropped down into the borehole from the upper layers of the cores (Fig. 9, C50; Fig. 10, C161; Fig. 12, C155); (2) a layer of $\mathrm{HMC}$ at the top band, then a gap of alluvial material before a further buried band of HMC (Fig. 12, C143); (3) HMC in a strong or weak band in the top $1.2 \mathrm{~m}$ of the core (Fig. 12, C148); (4) strongly indicated HMC in the lower bands of the core. In the case of type (3), such cores can perhaps be taken cautiously as being the kind of archaeology they indicate. If the HMC content is weak and consists of top-soil-containing material from manuring or is in the modern town where settlement layers can be thick, then it may indicate relatively modern activity.

In the agricultural area south of Sa el-Hagar, type (2) drill auger cores, comprising two bands of HMC separated by alluvium, are evidenced by 25 drill cores in the area southeast of the village alone, mostly in the area that was flooded by the palaeochannel that moved to the west. In a transect across the area (Fig. 4 red dots; Fig. 12), the upper layers of human material culture, for example in C148, contain fired brick and sherds that may be from the Roman period and modern material. The settlement material in the lower core bands, for example C143 and C151, is overlain and on top of alluvium and channel deposits and is not easy to date due to the small size of the pottery fragments. The fact that the material is in dense bands, along with some charcoal and brown-orange mottling suggests that the anthropogenic material is a primary deposit, and it is also spread over a wide area. The presence of another archaeological zone at Sa el-Hagar raises questions about what would have been the settlement or even the urban constitution of ancient Sais. With areas in the north, in the Great Pit and under the modern village, and to the southeast and perhaps areas around Sais, the conurbation seems to be a loose federation of settlements, perhaps operating at slightly different chronological time frames, but suggesting a dynamic and changing urban catchment area that was responsive to changes in the alluvial character of the river and its branches.

\section{Ancient topographies}

There is a description of part of the topography of Sais from an inscription on a granite statue in the Greco-Roman 

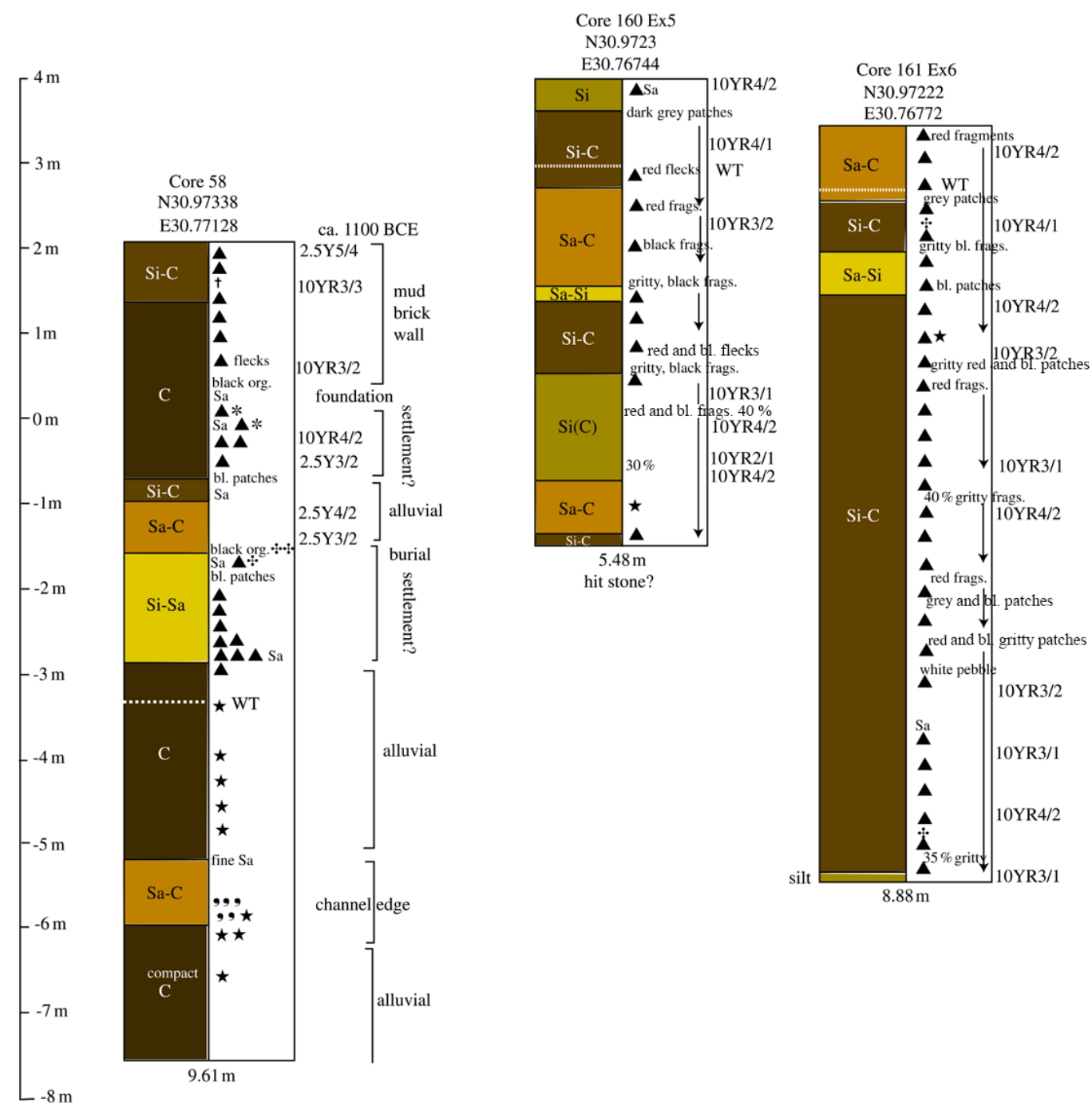

Figure 10. Drill cores in excavation trenches for Ex 1 (C58), Ex 5 (C160) and Ex 6 (C161) (see Fig. 13 for the key to cores).

museum in Alexandria (inventory no. 26532). The headless statue of man kneeling to present an offering table records the excavation of a lake at Sais by the "Administrator of the temples of Neith, Lector Priest, great Physician of Pharaoh, Royal Chancellor and Sole Companion Horkhebi" (Bakry, 1970; Geßler-Löhr, 1983, pp. 233-237). The decree from Ahmose II for the lake's construction was to enable water to be provided for purification purposes in the temple of Neith.

I excavated the lake on the east side of the Wuwu Canal; its width was 68 cubits, its length of $65 \mathrm{cu}-$ bits and built of [lime]stone, 8 stairways in it and walls around it.

The lake would have been a stone-lined structure with dimensions of around 34 by $32.5 \mathrm{~m}$, perhaps like the sacred lake at the Dendera temple in upper Egypt, for example (it is about 25 by $35 \mathrm{~m}$ in size and lined with sandstone blocks). The location "east of the Double Canal" may suggest that a local canal system could feed water into the lake to keep the lake supplied. The writing with two quail chick signs between two canal signs has suggested the translation "Double Canal", but can the inscription be used to locate either the sacred lake or the "Double Canal"? And how does this fit within the geoarchaeological topography of Sais as a whole? The sacred lake should have been in the sacred enclosure area near the temple of Neith, which was most likely in the Northern Enclosure. In this case, the canal would be to the west of the enclosure and may have been in the channel noted there and described above. The lake would be somewhere in the area of the western part of the enclosure. Unfortunately, the inscription does not give enough information to be certain about where to look for the sacred lake, although the buried stone debris features noted above may, at some point in the future, prove to be indicators of some such feature. The ancient texts then provide details which cannot yet be verified 

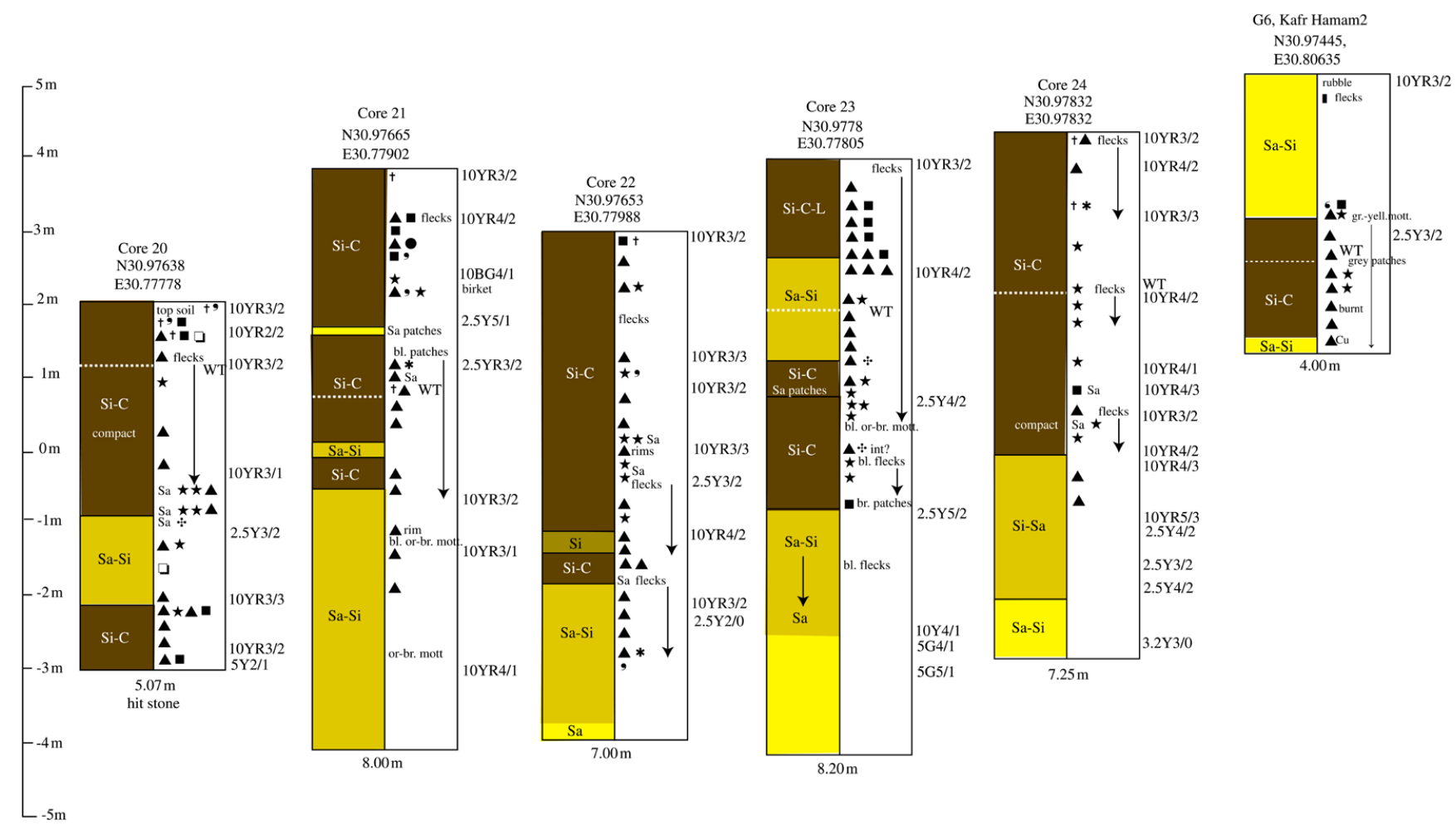

Figure 11. Transect in the Kawady elite cemetery area (C20, C21, C22, C23, C24 and KH2) (see Fig. 13 for the key to cores).
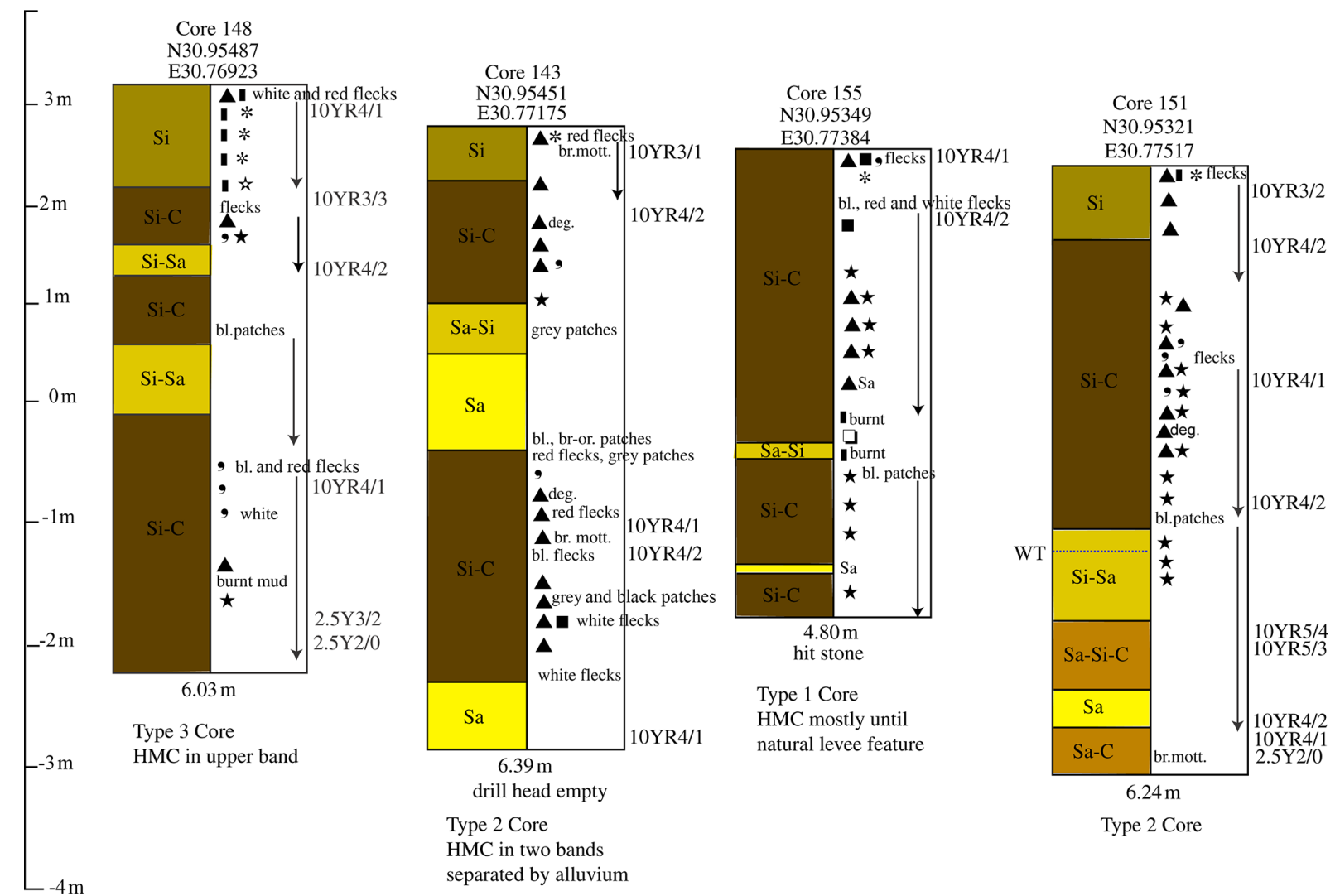

Figure 12. Transect south of Sa el-Hagar (C148, C143, C155 and C151) (see Fig. 13 for the key to cores). 


\begin{tabular}{|c|c|c|}
\hline \multicolumn{3}{|c|}{ Auger Key } \\
\hline \multirow{2}{*}{$\begin{array}{l}\text { Materials } \\
\text { Pottery sherds }\end{array}$} & \multicolumn{2}{|c|}{ Matrix descriptions } \\
\hline & & \\
\hline - Rounded clast & $\mathrm{C}$ & Clay \\
\hline \multicolumn{2}{|l|}{$\star$ Sharp, root clast } & \\
\hline 6 Shell (snail) & Si-C & Silt clay \\
\hline+ Roots of plants & $\mathrm{Si}$ & Silt \\
\hline$\because$ Bone & & \\
\hline * Organics & $\mathrm{Sa}-\mathrm{C}$ & Sand clay \\
\hline - Limestone & & \\
\hline$\square$ Sandstone & $\mathrm{Sa}-\mathrm{Si}$ & Sand silt \\
\hline$\nabla$ Faience & & \\
\hline \& Glass & $\mathrm{Sa}$ & Sand \\
\hline \multicolumn{3}{|l|}{ t Tafl (clay) } \\
\hline Colour descriptions & $\mathrm{L}$ & Loam \\
\hline bl. black & & \\
\hline br. brown & & Water \\
\hline orange & WT & Table leve \\
\hline mottling & & \\
\hline
\end{tabular}

Figure 13. Key for the auger logs.

on the ground and, so, are limited in specific identifications of water features at Sais.

\section{Summary}

The analysis of the subsurface material contributes to understanding why the area at Sais area was suitable for sustained settlement. First, the underlying sand and channels of the meandering river system meant that there was always some high, non-flooded land available, either because it was naturally high or humanly managed so that it was high (settlement tell) and dry (mud brick enclosure), with high ground for a cemetery. Second, the period of the initiation of the deposition of the Bilqas mud was a decisive change in settlement and riverine exploitation at Sais. The old palaeochannel system with Neolithic settlement on the west bank of the channel was replaced by a more stable river system, with settlements on the east bank. Third, the Sais archaeological zone is extensive, with settlements changing their original locations in the area, being abandoned and then returning to previously inhabited places. The complex record therefore contains evidence of human reactions to larger environmental changes and proactive interventions in the construction of agricultural and settlement facilities.

By linking some of the archaeological material with geological data, it is possible to go some way towards understanding the components of a settled area, especially if it is buried under modern towns and agricultural land. A city like Sais may have consisted of, perhaps, numerous settlements at any one time that were distributed around the general area. In ancient times, such settlements may have been part of the estates controlled by Sais itself from the main temple zones, and together the settlements may have constituted an admin- istrative unit. Further analysis of drill auger material, more targeted work in conjunction with floodplain geologists and dating and pollen analysis will yield significant information when collated and analysed. Most exciting is the potential for sites that have been mostly destroyed and removed to yield their information and further expand our knowledge of settlement patterns and the relationship with waterway dynamics in the Nile Delta floodplain.

Data availability. Data for the drill cores are available from the Archaeology Data Service at https://doi.org/10.5284/1081997 (Wilson, 2020).

The Landsat 5 imagery in Fig. 6 is part of the USGS Landsat 5 product (01198021202520009) from 14 February 1998, with 5 band wavelengths equal to 1.55 and 1.75 . The radiometric gains and/or bias are equal to. $0.1080784,-0.3700000$.

Author contributions. PW compiled the article, maps and auger interpretations. HG carried out the deep-drill coring and VES work and interpretation.

Competing interests. The authors declare that they have no conflict of interest.

Special issue statement. This article is part of the special issue "Geoarchaeology of the Nile Delta". It is a result of the workshop "Geoarchaeology of the Nile Delta: Current Research and Future Prospects", Würzburg, Germany, 29-30 November 2019.

Acknowledgements. Thanks are due to the following people: the drill teams (Ahmed el Bishe, Esmaiein el Bishe and Ibrahim Darawy) and their supervisors (Daniel Lines, Joshua Trampier, Karen Exell, Shakira Christodoulou, Gregory Gilbert and Mohamed Gaber). The professors Adam ElShahat, Hosni Ghazala, Mahmoud El-Gamili and Zeinab elSayed Belal and their teams from Mansoura University are thanked. For the discussions, we thank Benjamin Pennington, Angus Graham, Judith Bunbury, Willem Toonen and Israel Hinojosa-Baliño. For logistical support and local information, we extend our gratitude to the Ministry of Antiquities Tanta and Cairo, Inspectors Said el Assal, Emad el Shenawy and Fatma Ragab, the Egypt Exploration Society and Durham University.

Review statement. This paper was edited by Christopher Lüthgens and reviewed by Julia Meister and one anonymous referee.

\section{References}

Abrams, M. and Comer, D.: Multispectral and hyperspectral technology and archaeological applications, in: Mapping archaeolog- 
ical landscapes from space, edited by: Comer, D. C. and Harrower, M. J., Springer, New York, NY, 57-72, 2013.

Bakry, H. S.: A Family from Sais, Mitteilungen des Deutschen Archäologischen Instituts, Abteilung Kairo, 23, 69-74, 1968.

Bakry, H. S.: Two Saite Monuments of Two Master Physicians, Oriens Antiquus 9, 333-341, pl. XXXVIII-XL, 1970.

Barois, J.: Les irrigations en Égypte, first edn., librarie Polytechnique Ch. Béranger, Paris, 1904.

Bell, B.: Climate and the History of Egypt: the Middle Kingdom, Am. J. Archaeol., 79, 223-269, 1975.

El-Shahat, A., Ghazala, H., Wilson, P., and Belal, Z.: Lithofacies of the upper quaternary sequence of Sa el-Hagar area, Gharbiya Governorate, Nile Delta, Egypt, Journal of Geology and Geophysics, Mansoura University, 32, 79-110, 2005.

Geßler-Löhr, B.: Die heiligen Seen ägyptischer Tempel: ein Beitrag zur Deutung sakraler Baukunst im alten Ägypten, Hildesheimer Ägyptologische Beiträge, 21, Gerstenberg Verlag, Hildesheim, 1983.

Ghazala, H.: Landscape evolution during the Holocene at Sais Area based on the drilled boreholes and geoelectrical survey, unpublished report for the Sais Mission, 2005.

Ghazala, H., El-Shahat, A., Abdel Raouf, O., Wilson, P., and Belal, Z.: Geoelectrical investigations around Sa el-Hagar archaeological site, Gharbiya Governorate, Nile Delta, Egypt, Journal of Geology and Geophysics, Mansoura University, 32, 121-137, 2005.

Hartung, U., Ballet, P., Effland, A., French, P. G., Hartmann, R., Herbich, T., Hoffman, H., Hower-Tilmann, E., Kitagawa, C., Kopp, P., Kreibig, W., Lecuyot, G., Lösch, S., Marouard, G., Zink, A., Nerlich, A., Pithon, M.: Tell el-Fara'in - Buto. 10. Vorbericht, Mitteilungen des Deutschen Archäologischen Instituts, Abteilung Kairo 65, 172-188, 2009.

Hritz, C.: Contributions of GIS and Satellite-based Remote Sensing to Landscape Archaeology in the Middle East, J. Archaeol. Res., 22.3, 229-276, 2014.

Pennington, B. T.: Environmental Change in Deltaic Settings and the Emergence of Civilization. A study in palaeolandscape construction focussing on the mid-Holocene Nile Delta, available at: https://eprints.soton.ac.uk/424723/1/Ben_Pennington_ PhD_Thesis_final_copy.pdf (last access: 13 May 2021), unpublished PhD Dissertation, Southampton University, Southampton, UK, 2017.

Pennington, B. T., Bunbury, J., and Hovius, N.: Emergence of Civilization, Changes in Fluvio-Deltaic Style and Nutrient Redistribution Forced by Holocene Sea-Level Rise, Geoarchaeology, 31, 194-210, 2016.

Pennington, B. T., Sturt, F., Wilson, P., Rowland, J., and Brown, A. G.: The fluvial evolution of the Holocene Nile delta, Quaternary Sci. Rev., 170, 212-231, https://doi.org/10.1016/j.quascirev.2017.06.017, 2017.
Pope, K. O. and Dahlin, B. H.: Ancient Maya Wetland Agriculture: New Insights from Ecological and Remote Sensing Research, J. Field Archaeol., 16.1, 87-106, 1989.

Toonen, W. H., Graham, A., Pennington, B. T., Hunter, M. A., Strutt, K. D., Barker, D. S., Masson-Berghoff, A., and Emery, V. L.: Holocene fluvial history of the Nile's west bank at ancient Thebes, Luxor, Egypt and its relation with cultural dynamics and basin-wide hydroclimatic variability, Geoarchaeology, 33, 273290, 2017.

Ullmann, T., Nill, L., Schiestl, R., Trappe, J., Lange-Athinodorou, E., Baumhauer, R., and Meister, J.: Mapping buried paleogeographical features of the Nile Delta (Egypt) using the Landsat archive, E\&G Quaternary Sci. J., 69, 225-245, https://doi.org/10.5194/egqsj-69-225-2020, 2020.

USGS: Fact Sheet 2015-3081, ver. 1.2, available at: https://pubs.usgs.gov/fs/2015/3081/fs20153081.pdf (last access: 18 May 2021), Landsat Earth Observation Satellites, 2020.

Vercoutter, J.: Semna South fort and the records of the Nile levels at Kumma, Kush: Journal of the Sudan Antiquities Service, 14, 125-164, 1966.

Wilson, P.: The Survey of Saïs (Sa el-Hagar), 1997-2002, Egypt Exploration Society, Excavation Memoir 77, Egypt Exploration Society, London, 2006.

Wilson, P.: Sais I: The Ramesside-Third Intermediate Period at Kom Rebwa, Egypt Exploration Society, Excavation Memoir 98, Egypt Exploration Society, London, 2011.

Wilson, P.: The Prehistoric Sequence at Sais: Temporal and Regional Connections, in: The Nile Delta as a centre of cultural interactions between Upper Egypt and the Southern Levant in the 4th millennium BC, edited by: Maczynska, A., Poznan Archaeological Museum, Poznan, Poland, 299-318, 2014.

Wilson, P., Gilbert, G., and Tassie, G.: Sais II: The Prehistoric Period, Egypt Exploration Society, Excavation Memoir 107, Egypt Exploration Society, London, 2014.

Wilson, P.: Royal City of Sais, York: Archaeology Data Service [distributor], https://doi.org/10.5284/1081997, 2020.

Wunderlich, J.: Untersuchungen zur Entwicklung des westlichen Nildeltas im Holozän, $\mathrm{PhD}$ thesis, Philipps-Universität, Marburg, West Germany, 1989.

Zhao, X., Thomas, I., Salem, A., Alassal, S., Liu, Y., Sun, Q., Chen, J., Fuwei, M., Finlayson, B., and Chen, Z.: Holocene climate change and its influence on early agriculture in the Nile Delta, Egypt, Paleogeography, Palaeoclimatology, Palaeoecology, 547, 109702, https://doi.org/10.1016/j.palaeo.2020.109702, 2020. 